\title{
Plasmodial enzymes in metabolic pathways as therapeutic targets and contemporary strategies to discover new antimalarial drugs: a review
}

\author{
Nurhainis Ogu Salimª, Noor Azian Md Yusuf ${ }^{\mathrm{b}}$, Fazia Adyani Ahmad Fuad ${ }^{\mathrm{a}}$ \\ ${ }^{a}$ Department of Biotechnology Engineering, Faculty of Engineering, International Islamic University Malaysia, PO Box 10, 50728 Kuala \\ Lumpur, Malaysia Malaysia \\ ${ }^{b}$ Parasitology Unit, Institute for Medical Research (IMR), National Institute of Health Complex, No. 1, Jalan Setia Murni U13/52, Seksyen \\ U13, Bandar Setia Alam, 40170 Shah Alam, Selangor, Malaysia
}

Received 30th November 2018 / Accepted 15th August 2019

\begin{abstract}
Malaria continues to pose imminent threat to the world population, as the mortality rate associated with this disease remains high. Current treatment relies on antimalarial drugs such as Artemisinin Combination Therapy (ACT) are still effective throughout the world except in some places, where ACT-resistance has been reported, thus necessitating novel approaches to develop new anti-malarial therapy. In the light of emerging translational research, several plasmodial targets, mostly proteins or enzymes located in the parasite's unique organelles, have been extensively explored as potential candidates for the development of novel antimalarial drugs. By targeting the metabolic pathways in mitochondrion, apicoplast or cytoplasm of Plasmodium, the possibility to discover new drugs is tremendous, as they have potentials as antimalarial therapeutic targets. This literature review summarizes pertinent information on plasmodial targets, especially enzymes involved in specific metabolic pathways, and the strategies used to discover new antimalarial drugs.
\end{abstract}

Keywords: Plasmodium enzymes, metabolic pathways, antimalarial target, drug discovery

\section{INTRODUCTION}

Despite the reduced numbers of malaria cases in the world, the morbidity and mortality rates remain disturbing. The World Health Organization (WHO) in 2017, reported that 219 million malaria cases have been registered worldwide. From this number, almost $92 \%$ of the cases occurred in WHO African Region, WHO South-East Asia Region (5\%) and the Eastern Mediterranean (2\%) regions (WHO, 2018). Malaria is caused by the parasites from genus Plasmodium, where infected Anopheles mosquitoes play a role as the transmission vector. Human infection with Plasmodium is normally associated with four species; specifically, Plasmodium falciparum, P. vivax, P. malariae and P. ovale. P. ovale that caused malaria in human can be divided into two distinct ovale malaria species, which are $P$. ovale curtisi and $P$. ovale walkeri, after a study conducted by researchers from Mahidol University, Bangkok and UK Malaria Reference Laboratory, where polymorphisms in six loci were observed in 55 isolates. It was found that two diverse major haplotypes of each locus were identified and these did not recombine in any of the parasites examined (Alemu et al., 2013; Rowe et al., 2006; Sutherland et al., 2010)

The recent distribution of Plasmodium species shows that majority of $P$. falciparum infection

*Author for correspondence: Fazia Adyani Ahmad Fuad, Department of Biotechnology Engineering, Faculty of Engineering, International Islamic University Malaysia, PO Box 10, 50728 Kuala Lumpur, Malaysia. Email fazia_adyani@iium.edu.my 
occurred in tropical Africa, while P. vivax infection happens more in South America, compared to $P$. falciparum. Meanwhile, in South-eastern Asia and Western Pacific, both $P$. falciparum and $P$. vivax are prevalent. Even though P. malariae could arise in all malarious areas, the $P$. malariae prevalence is usually low. Meanwhile in tropical Africa, P. ovale is prevalent and sometimes $P$. falciparum and $P$. malariae co-infection is found (Autino et al., 2012). However, in the recent years, the fifth human malaria parasite, known as $P$. knowlesi that was formerly infecting monkeys has been discovered, raising concerns on zoonotic transmission (White, 2008). P. knowlesi infection occurs only in forested area in certain countries in South-East Asia (Autino et al., 2012). The zoonotic malaria species $P$. knowlesi has become the main cause of human malaria in Malaysian Borneo (Fornace et al., 2016; William et al., 2011; Yusof et al., 2016).

The clinical features shown on malaria patients usually appear during parasite's maturation in human blood and the symptoms emergence coincides with the release of antigens during the host cell rupture (Trampuz et al., 2003). According to its severity, malaria is usually classified as uncomplicated (or mild) or complicated (severe) (Phillips et al., 2017). To circumvent severe illness or fatality, an appropriate management of malaria is vital. At present, malaria treatment according to the standard treatment recommended by the WHO, is Artemisinin Combination Therapy (ACT) as the first line of malaria treatment for countries that are prevalent with $P$. falciparum infection. In areas of multidrug resistance (South-East Asia), drugs presently used for malaria treatment including combination of artemether-lumefantrine or artesunate + mefloquine while in Africa artemether-lumefantrine, artesunate + amodiaquine, or artesunate + sulfadoxinepyrimethamine is used. The second line treatment could be alternative of ACT, quinine + tetracycline or doxycycline or clindamycin. Chloroquine is generally used for $P$. vivax, P.ovale and P. malariae. (CDC, 2015; WHO, 2015).

The reduction of death due malaria nowadays is largely contributed by the collective efforts of adoption of new-artemisinin-based medicine, increased of investments for research and development that leads to improvements in antimalarial treatments. Jagoe mentioned in the
Medicine for Malaria Ventures (MMV) that a single dose treatment has been introduced in 2018 for vivax malaria. The current treatment always lead to poor compliance because of the treatment period; this could replace the current 14 days treatment to stop relapse (Jagoe, 2018). The trial for the new vivax malaria treatment was performed in Brazil, Cambodia, Ethiopia Peru, Philippines and Thailand, where they have selected 522 malaria patients with confirmed infection with $P$. vivax and normal glucose-6phosphate dehydrogenase (G6PD), resulted in significantly lower risk of recurrence of $P$. vivax as compared to placebo in patient with normal G6PD activity (Lacerda et al., 2019).

Many approaches using the latest technology has been conducted to develop new drug candidates for the treatment of antimalarials, as alternative to the currently available treatments. Four years ago, a team at MVV lead by Burrows and colleagues has established an outline for malaria drug design by defining the minimum acceptable profile of target candidates and target product for developing a novel malaria therapy. Target candidate profile (TCP) with their mechanism of action has been listed out in their review. Each TCP has their own mechanism of actions, as for example TCP1 targeted molecules that would clear asexual plasmodial blood stages in patients, while TCP3 aim the molecule that aids in clearing the dormant hypnozoites as prevention of relapses due to $P$. vivax or $P$. ovale infections. Meanwhile, TCP4 and TCP5 have different target where TCP4 targeted molecules that can clear the liver stage infection. However, TCP5 and TCP6 action by blocking the transmission, TCP5 rendering the gametocyte non-functional and TCP6 kill the mosquito following a blood meal (Burrows et al., 2017). MMV predicted that only less than two percent of project for new antimalarial will proceed to final stage of clinical trial.

Okombo and Chibale reviewed in 2018 on the latest progress of drug candidates as described in MMV and the NIH-hosted repository for clinical trials. A literature search was performed by Okombo and Chibale from articles in the life sciences journal archive and PubMED that was published in the last five to six years, where it was described that the drug candidate for antimalaria at present are under various phases of 
consideration for development. Six drugs were at lead optimization stage, five drugs are at preclinical stage, three antimalarial drugs candidates are already for clinical evaluation and additional six drug candidates are in product development under patient exploratory stage. These current discoveries will require long term investments, scientific venture and political support to warrant the decrease of disease burden globally (Okombo \& Chibale, 2018).

\section{Antimalarial resistance}

Over the years, the efficacy of most antimalarial drugs is declining, which is mainly due to the more widespread resistance. This issue is further exacerbated by the fact that the compounds currently used in malaria treatment share related mechanisms of action. This hinders the efforts to reduce the morbidity and mortality rates related to this disease (Olliaro \& Mussano, 2003). Resistance of $P$. falciparum towards antimalarial starting from the first report of quinine resistance in 1910, followed by chloroquine in 1960 (Blount 1967; da Silva \& Benchimol, 2014; Tan et al., 2014). An analysis of molecular, genetic and biochemical approaches to $P$. falciparum gene resistance towards chloroquine has been conducted by Le Bras \& Durand (2003), which the study aimed to elucidate $P$. falciparum multidrug resistance 1 gene $(\phi f m d r 1)$. The authors identified a gene on chromosome 5, encoding a P-glycoprotein homolog 1 and $P$. falciparum chloroquine resistance transporter $(p f c r t)$ on chromosome 7 as the main determinants of chloroquine resistance. Their findings have also shown that mutations in $p f m d r 1$ and pfort genes eventually lead to chloroquine resistance. Mutations in these genes causes reduction in chloroquine uptake by the parasite's vacuole (Le Bras \& Durand, 2003; Ibraheem et al., 2014). Chloroquine resistance of $P$. vivax has already grasped a worrying prevalence in Indonesia, East Timor and Papua New Guinea. Recently, chloroquine resistance of $P$. vivax infections in Guyana, Peru and Brazil has been investigated in in vivo studies (Gonçalves et al., 2014). In the same year, molecular evidence of increased resistance to chloroquine and sulphadoxine/pyrimethamine has been reported. Both in vivo treatment efficacy and molecular assays were used to identify the range of $P$. falciparum resistance towards both drugs in two of north-east Indian state. The study reported 81.5\% treatment failure for chloroquine and 13.7\% treatment failure to sulphadoxine / pyrimethamine. Moreover, $99 \%$ of the failure had mutant $p$ fort genotype (76T), while $68 \%$ had mutant of $p f m d r-1$ genotyoe (86Y). The study indicates high level of resistance was observed in North-east India and it triggered an alarm for malaria management in north-east India (Mohapatra et al., 2014). Another study conducted during 2008-2013 in Kolkata and Purulia, India, resulted in a rise of in vitro chloroquine resistance to $P$. falciparum, even after five years following chloroquine withdrawal (Das et al., 2017).

Since chloroquine is no longer used in treating $P$. falciparum infection, a standardized treatment using ACT has been employed to replaced chloroquine. Presently, ACT is still the most effective treatment for malaria since to date, no other alternative treatment can match its potency (WHO, 2015). However, in an earlier study, Rogers et al. (2009) found that artesunatemefloquine, a type of ACT antimalarial, has started to fail in southern Cambodia (Rogers et al., 2009). P. falciparum resistance to artemisinin has also been identified in the Greater Mekong Subregion including Cambodia, Myanmar, Laos, Thailand and Vietnam (WHO 2018). The mutations in the kelch propeller (K13-propeller) domain has been associated with the development of artemisinin resistance involving point mutations at Y493H, C580Y, M476I, R539T and I543T (Ariey et al., 2014; Straimer et al., 2015). The development of $P$. falciparum resistance towards artemisinin derivatives is causing limited efficacy of the current antimalarial drugs (Ringwald et al., 2012). An investigation into the efficacy and safety of artemisinin-based antimalarials in the treatment of uncomplicated malaria for children in southern Tanzania indicated that artemetherlumefantrine (AL) is very efficacious in areas of high sulphadoxine-pyrimethamine (SP) resistance (Kabanywanyi et al., 2007). More recently, Hastings et al. (2014) reported that artemisinin component typically shows insignificant contribution $(<0.0001 \%)$ to the therapeutic capacity of the most widely used ACTs (Hastings \& Hodel, 2014). On the other hand, a study to determine the efficacy of conventional antimalarials against $P$. knowlesi, the fifth human malaria parasite, revealed that it is uniformly 
highly sensitive to artemisinin, variably and moderately sensitive to chloroquine, and less sensitive to mefloquine (Fatih et al., 2013). Table 1 summarized the regions where antimalaria drug resistance have been reported with respective molecular markers.

Thus, there is a vital need to identify novel targets that can be employed in the improvement of the next generation of antimalarial drugs. Since antimalarial drugs are a vital component of disease control and elimination, potential failure of these drugs in the future would hinder the efforts dedicated to disease eradication and treatment. The aim of this review is to elucidate the applicability of enzymes found in Plasmodium spp. as possible therapeutic targets in combating malaria. In order to achieve this objective, pertinent information related to antimalarial targets, especially the enzymes involved in specific pathways, the mechanism of action of the enzymes and inhibitors, as well as the strategies used to discover new antimalarial drugs are discussed and presented in the following sections.

Table 1. Specific regions where antimalaria drug resistance have been reported with their respective molecular markers

\begin{tabular}{|c|c|c|c|c|}
\hline Drugs & Species & Region & Molecular marker & Reference \\
\hline Chloroquine & P. falciparum & & $\begin{array}{l}\text { Mutation on } p f m d r 1 \\
\text { and } p f c r t \text { genes }\end{array}$ & $\begin{array}{c}\text { (Le Bras \& Durand, } \\
2003)\end{array}$ \\
\hline Chloroquine & P. vivax & $\begin{array}{c}\text { Indonesia, East } \\
\text { Timor, Papua New } \\
\text { Guinea Guyana, } \\
\text { Peru and Brazil }\end{array}$ & & (Gonçalves et al., 2014) \\
\hline $\begin{array}{l}\text { Chloroquine } \\
\text { and } \\
\text { sulphadoxine } \\
\text { /pyrimethamine }\end{array}$ & P. vivax & North-east India & $\begin{array}{l}\text { Mutation on } p f m d r 1 \\
\text { and } p f c r t \text { genes }\end{array}$ & (Mohapatra et al., 2014) \\
\hline Chloroquine & P. falciparum & $\begin{array}{l}\text { Kolkata and } \\
\text { Purulia, India }\end{array}$ & & (Das et al., 2017) \\
\hline $\begin{array}{l}\text { Artesunate- } \\
\text { mefloquine }\end{array}$ & P. falciparum & Southern Cambodia & & (Rogers et al., 2009) \\
\hline Artemisinin & P. falciparum & $\begin{array}{c}\text { Cambodia, } \\
\text { Myanmar, Laos, } \\
\text { Thailand and } \\
\text { Vietnam }\end{array}$ & $\begin{array}{l}\text { Mutations in the } \\
\text { kelch propeller } \\
\text { (K13-propeller) }\end{array}$ & (WHO, 2018) \\
\hline $\begin{array}{l}\text { Sulphadoxine- } \\
\text { pyrimethamine }\end{array}$ & & Tanzania & & $\begin{array}{l}\text { (Kabanywanyi et al, } \\
\text { 2007) }\end{array}$ \\
\hline
\end{tabular}

\section{Antimalarial target}

Over the years, most of the antimalarial drug discovery efforts tend to focus on parasitespecific processes, such as hemoglobin degradation, parasite's egress from the host cell, and host cell invasion by the parasite. As these approaches are becoming increasingly ineffective in combatting and treating malaria, it is essential to conduct further studies aiming to identify new targets for the development of antimalarial drugs.
The findings are expected to facilitate construction of new compounds that can interact with the target receptor to diminish the malaria parasite. Targets such as mitochondrion, apicoplast and cytoplasm of Plasmodium have been studied extensively in extant studies and their potential as drug targets has been elucidated. Table 2 summarizes the Plasmodial enzymes in metabolic pathways that have been identified as drug targets. 
Table 2. Plasmodial enzymes in metabolic pathways as therapeutic targets.

\begin{tabular}{|c|c|c|c|}
\hline Metabolic pathway & Inhibitor & Therapeutic target & References \\
\hline $\begin{array}{l}\text { Iron and heme } \\
\text { metabolism }\end{array}$ & $\begin{array}{c}\text { Artemisinin and its } \\
\text { derivatives }\end{array}$ & $\begin{array}{c}\text { Pf ring stage activates } \\
\text { ART }\end{array}$ & $\begin{array}{l}\text { (Klonis, Creek, \& Tilley, } \\
\text { 2013) }\end{array}$ \\
\hline \multirow{4}{*}{$\begin{array}{c}\text { Pyrimidine biosynthesis } \\
\text { pathway }\end{array}$} & $\begin{array}{c}\text { Small molecule species } \\
\text { specific inhibitors of } \\
\text { Plasmodium falciparum } \\
\text { DHOD }\end{array}$ & $\begin{array}{l}\text { Dihydroorotate } \\
\text { dehydrogenase }\end{array}$ & (Patel et al., 2008) \\
\hline & $\begin{array}{c}\text { Triazolopyrimidine- } \\
\text { based }\end{array}$ & $\begin{array}{l}\text { Dihydroorotate } \\
\text { dehydrogenase }\end{array}$ & (Gujjar et al., 2009) \\
\hline & $\begin{array}{l}\text { Aryl and aralkyl amine- } \\
\text { based triazolopyrimidine }\end{array}$ & $\begin{array}{l}\text { Dihydroorotate } \\
\text { dehydrogenase }\end{array}$ & (Gujjar et al., 2011) \\
\hline & $\begin{array}{l}\text { SPROUT-designed } \\
\text { inhibitors (a software } \\
\text { package for structure- } \\
\text { based drug discovery } \\
\text { and lead optimization). }\end{array}$ & $\begin{array}{l}\text { Dihydroorotate } \\
\text { dehydrogenase }\end{array}$ & (Davies et al., 2009) \\
\hline \multirow{2}{*}{$\begin{array}{l}\text { Mitochondrial inner } \\
\text { membrane enzyme }\end{array}$} & $\begin{array}{c}\text { Tetracyclic } \\
\text { benzothiazepines }\end{array}$ & Cytochrome bc1 & (Dong et al., 2011) \\
\hline & $4(1 \mathrm{H})$-pyridones & Cytochrome bc1 & (Bueno et al., 2012) \\
\hline Mitochondrion & $\begin{array}{c}\text { Heterocyclic } \\
\text { Quinolones }\end{array}$ & $\begin{array}{c}\text { NADH: ubiquinone } \\
\text { oxidoreductase }\end{array}$ & (Leung et al., 2012) \\
\hline \multirow{4}{*}{ Folate pathway } & Antifolates & $\begin{array}{c}\text { Dihydrofolate reductase } \\
\text { and dihydropteroate } \\
\text { synthase }\end{array}$ & (Hyde et. al., 2005) \\
\hline & $\begin{array}{l}\text { Sulfur based drugs } \\
\text { (analogs of } \\
\text { sulphanilamide) }\end{array}$ & $\begin{array}{l}\text { Dihydropteroate } \\
\text { synthase }\end{array}$ & (Nzila et. al., 2006) \\
\hline & Quinazolinones & Dihydrofolate reductase & (Patel et al., 2017) \\
\hline & $\begin{array}{c}\text { GTP analogue inhibitor } \\
\text { (8-oxo-GTP) }\end{array}$ & GTP cyclohydrolase I & $\begin{array}{l}\text { (Kümpornsin et al., } \\
\text { 2014) }\end{array}$ \\
\hline \multirow{6}{*}{ Glycolytic pathway } & Galloflavin & Lactate dehydrogenase & (Manerba et al., 2012) \\
\hline & $\begin{array}{c}\text { Itraconazole, } \\
\text { atorvastatin and } \\
\text { posaconazole }\end{array}$ & Lactate dehydrogenase & $\begin{array}{l}\text { (Penna-Coutinho et al., } \\
\text { 2011) }\end{array}$ \\
\hline & Azole-based compound & Lactate dehydrogenase & (Cameron et al., 2004) \\
\hline & 3-Br-isoxazoline & $\begin{array}{l}\text { Glyceraldehyde-3- } \\
\text { phosphate } \\
\text { dehydrogenase }\end{array}$ & (Bruno et al., 2016) \\
\hline & $\begin{array}{c}\text { Analogues of inorganic } \\
\text { diphosphate }\end{array}$ & T. cruqi hexokinase & (Hudock et al., 2005) \\
\hline & $\begin{array}{l}\text { PfHK inhibitors with } \\
\text { antiparasitic activity }\end{array}$ & hexokinase & (Davis et al., 2016) \\
\hline
\end{tabular}

\subsection{The mithochondrian target}

According to Goodman et al., 2017, Plasmodium mitochondrion is an effective drug target with safe effective drugs for medical use. The mitochondrion is an organelle that plays a key role in the eukaryotic cell energy production. Plasmodium mitochondrion, a single tubular organelle structure (6-kb mtDNA) is highly fragmented rRNA gen and only encodes three genes for proteins (Das et al., 1997; Hikosaka et al., 2011). Plasmodium and the host's mitochondrial are different in terms of molecular and their function. Plasmodial mitochondrial is essential in the parasite's life cycle (Lunev et al., 2016), where mitochondrion dysfunctional can cause cell death. An overview of studies examining mitochondria 
of Plasmodium as a drug target conducted by Hikosaka et al. (2015) indicated that the enzymes of mitochondrial tricarboxylic acid (TCA) cycle and mitochondrial electron transport chain (mtETC) are attractive drug targets. TCA cycle, also known as Krebs cycle, is one of the important stages in aerobic respiration. It is well-established that the substrate for TCA cycle is acetyl-CoA from pyruvate oxidation or fatty acid/protein degradation. Lunev et al. (2016) also has discussed in detail regarding the potential pathways of the mitochondrial and carbon metabolisms, such as pyrimidine biosynthesis, aspartate metabolism and mitochondrial tricarboxylic acid (TCA) cycle as drug targets in P. falciparum (Lunev et al., 2016). Although P. falciparum possesses all enzymes of the TCA cycle, it has been suggested that at least the asexual stages do not require TCA cycle for energy generation (van Dooren, Stimmler and McFadden 2006) and rely on glycolysis and fermentation for energy (Vander Jagt et al., 1990). Moreover, Hikosaka et al. (2015) cautioned that drug targeting TCA cycle and mtRTC was a difficult approach, as it required rigorous biochemical analysis due to the complexity associated with obtaining intact and pure mitochondria from the parasites. Furthermore, studies mentioned that during erythrocytic cycle of plasmodium, oxidative phosphorylation is not crucial for the Plasmodium as the parasites depend mainly on glycolysis for the source of energy to survive during the blood stage (Ke et al., 2015; MacRae et al., 2015; Bryant et al., 1964; Roth et al., 1988). Thus, Lunev et al., (2016). generally believed that the role of mitochondria in the parasite during blood stage is mainly for the maintenance of inner mitochondrial potential Hence, designing antimalarial drugs by targeting the mitochondrion, specifically by failing the inner mitochondrial potential and inhibit Plasmodium growth is still relevant, as it may potentially deliver new drugs for malaria treatment.

Nevertheless, mitochondrial electron transport remains as target for the existing and new antimalarials. An analysis has suggested that a mixture of chloroquine or its analogue, together with another drug, inhibits carbon fixation and/or increases oxidative stress, where this should increase the clearance of $P$. falciparum from the host system (Tewari et al., 2017). Compounds such as atovaquone are known to target the mitochondrial electron transport chain, since it blocks the flux of metabolites through the TCA cycle (Ke et al., 2015).The details of the studies of enzymes in these pathways are tabulated in Table 2.

Even though malaria parasite's mitochondria metabolic processes are limited, and less pathways appear during the intraerythrocytic cycle for the parasite survival, it is encouraging that various number of compounds selectively aiming Plasmodium mitochondrion. Inhibition of mitochondria resulting in accumulation of free fatty acid and triglycerides in the cytoplasm and their derivatives, which have toxic effects potential on mitochondrial respiration, ketone body production, gluconeogenesis and ATP synthesis (Olszewska \& Szewczyk, 2013).

\subsection{Apicoplast target}

Apicoplast (vestigial plastid) is a chloroplast-like organelle characterized by a unique nonphotosynthetic plastid. Apicoplast can be found in most parasites of Phylum Apicomplexa, a name derived from apical complex, except in Cryptosporidium spp. (Köhler et al., 1997; McFadden et al., 1996). Apical complex is an anterior structure that allows the parasite to invade the host cells and establish themselves in the host. Apicoplast is a specialized organ located below apical complex that performs multiple functions but its capacity to photosynthesize is limited. In addition, it holds a wide range of metabolic pathways that can be used by the parasite. Some of the product components are critical for the host cell invasion (Ralph et al., 2001; Mukherjee \& Sadhukhan, 2016). However, apicoplast retains the typical plastid functions, such as isoprenoid, fatty acid, and haem syntheses (Table 1), while also carrying cellular processes, such as deoxyribonucleic acid (DNA) replication, transcription, translation, and post-translational modification (Mukherjee \& Sadhukhan, 2016). Nonetheless, the reason why apicoplast is essential to the parasite's survival is still unknown (Lim \& McFadden, 2010).

Apicoplast as an antimalarial drug target has been examined by several researchers (Botté et al., 2012; Mukherjee and Sadhukhan 2016; Ralph, D'Ombrain, \& McFadden, 2001). According to their findings, the apicoplast target for antimalarial is based on the metabolic activity in 
the Plasmodium itself. As reviewed by Mukherjee \& Sadhukhan (2016), in apicoplast DNA replication, gyrase A (GyrA) and gyrase B (GyrB) play an important role in Plasmodium, where DNA cleavage and wrapping domains were located in GyrA subunit, whereas adenosine triphosphase (ATPase) and DNA binding/GyrA interaction domains are present in the $\mathrm{GyrB}$ subunit, where this structure exhibit strong homology to Escherichia coli. In E. coli, aminocoumarin drug novobiocin inhibits the ATPase activity of GyrB, while in $P$. falciparum the drug was shown to competitively inhibit the apicoplast's ATPase activity and DNA replication, which causing a lag in conversion of the parasite's stages from trophozoite to schizont stage. Novobiocin also disrupt the activity of $P$. falciparum GyrB ATPase that causes the parasite's death in cultures. On the other hand, the review also mentioned ciprofloxacin, which shown to inhibit apicoplast DNA replication in $P$. falciparum (Mukherjee \& Sadhukhan, 2016).

In a more recent study, Rai et al. (2017) noted that understanding of the function of apicoplasts will benefit in designing better therapeutics through calcium signaling because it plays a vital role in the development and growth of Plasmodium, specifically in apicoplast transcriptional regulation (Cheemadan et al., 2014; M. Rai et al., 2017). Cheemadan et al. (2014) studied the role of calcium signaling in the transcriptional regulation of the apicoplast genome of $P$. falciparum. In order to assess the effect of changing calcium distribution within the cell, the transcriptional responses of $P$. falciparum to two calcium ionophores was analysed. It was found that both inhibitors induced overlapping but not identical changes of the $P$. falciparum transcriptome. However, both inhibitors caused strong inhibition of transcriptional activity of all the important genes in the apicoplast genome. Due to this situation, the authors identified MAL13P1.156, which is a nuclear encoded apicoplast targeted protein that transports a calcium binding domain. Overexpression of the protein causing resistance of $P$. falciparum towards ionomycin and it was proposed that this protein possibly play an important role in calcium dependent signaling pathways in apicoplast (Cheemadan et al., 2014).
In addition, apical membrane antigen 1 (AMA1) is one of the components in the invasion machinery of Plasmodium. AMA1 was found to be an important candidate for malaria vaccine. A review beheld at both structural details and functional significance of interactions at the hydrophobic cleft of AMA1 have been elucidated and it is suggested as an ideal target for the development of drugs that can prevent host cell invasion by malaria parasites (Macraild et al., 2011).

\subsection{Cytoplasmic target}

An apicomplexan including Plasmodium spp., Toxoplasma gondii, and Cryptosporidium parvum, as well as opportunistic pathogens of immunocompromised individuals Eimeria spp. and Theileria spp., share distinct morphological features and cytoskeletal organization. Cytoskeletal system is multifaceted, comprising of interlinking filaments and tubules that spread throughout the cytoplasm. In Plasmodium, various metabolic pathways can be found in the cytoplasm, such as, folate metabolism and glycolysis. These metabolic pathways consist of hundreds of enzymes that may be potential drug targets (Gardner et al., 2002). A general overview adapted and modified from Gardner et al., 2002 on these pathways is shown in Figure 1.

\subsection{Enzymes involved in folate pathway}

Empirical evidence also indicates that folate pathway is vital for synthesizing amino acids, as it is important for building of proteins for the malaria parasites survival. By referring to previous literatures regarding folate pathway, several drugs were developed to disrupt folate pathway with the aim of developing new treatment and prophylaxis for malaria. Folate pathway is also critical in providing cofactors for the metabolic events. The enzymes in this pathway serve as molecular targets, including dihydrofolate reductase (DHFR) and dihydropteroate synthase (DHPS). DHFR aids in the oxidation of tetrahydrofolate (THF) molecule to DHF and its reconversion to the THF form (Hyde, 2005). DHPS is an enzyme with two binding pockets, one of which binds to dihydropterin pyrophosphate (DHPP), while the other binds with p-amino benzoic acid (pABA). DHPS catalyzes the reaction that produces 7,8 dihydropteroate from these two substrates. 


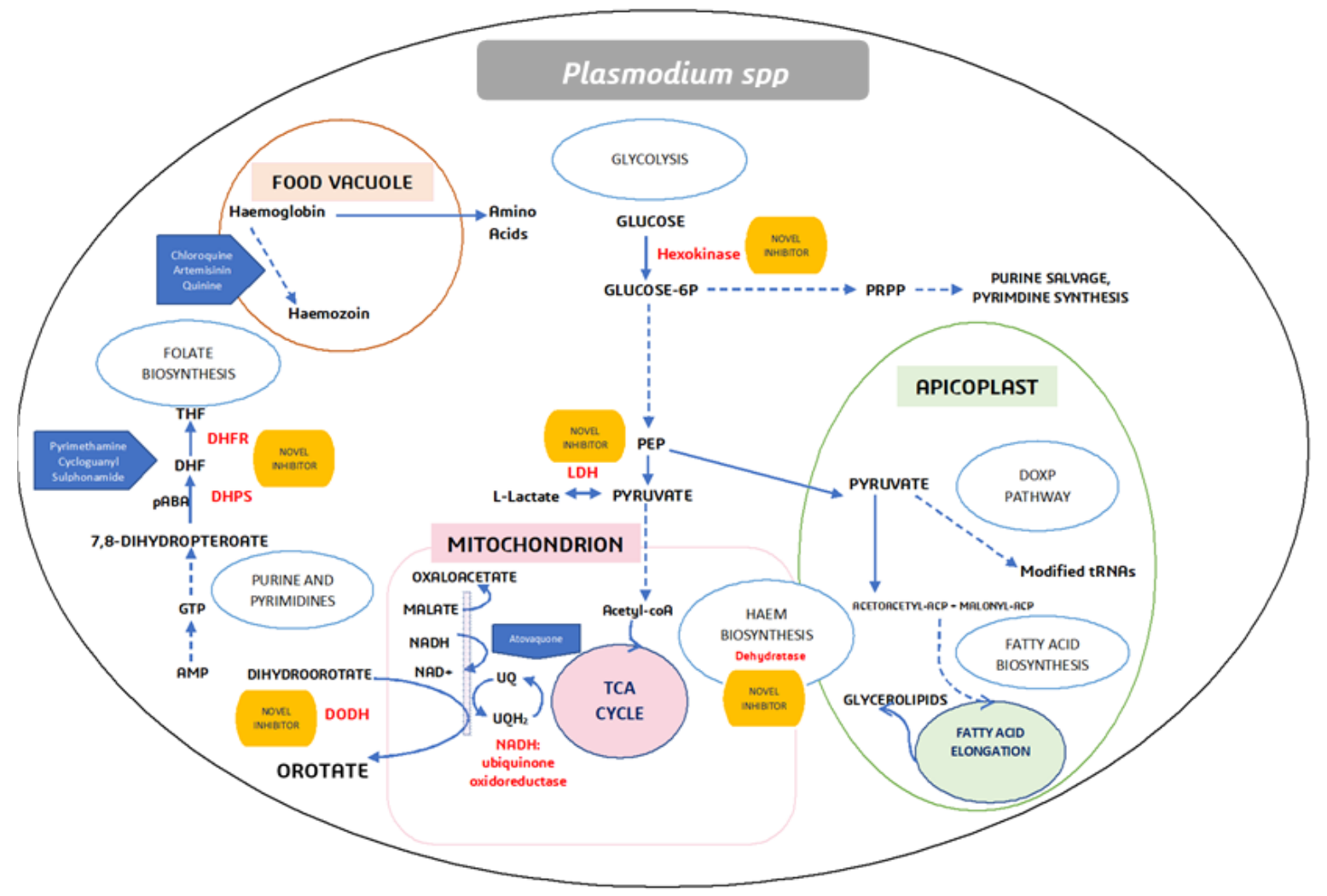

Figure 1. General overview of metabolism pathways and potential target for novel inhibitor in Plasmodium spp. Figures adapted and modified from Gardner et al., (2002).

Among the antimalarial drugs presently in use, the antifolates have emerged as the most promising owing to their well-defined molecular targetsdihydrofolate reductase (DHFR) and dihydropteroate synthase (DHPS) — that are also involved in the folate metabolic pathway. Antifolates are inhibitors of folate synthesis or folate conversions and are currently used for malaria treatment. These are first-line drugs in some of the African countries, as they are a costeffective choice for fighting chloroquine-resistant malaria (Hyde, 2005). The antifolates have also been developed as synergistic combinations of DHFR and DHPS inhibitors. Antifolates, such as sulfur-based drugs, which are analogs of sulfanilamide, can inhibit DHPS. These compounds compete with para-aminobenzoic acid in the DHPS active site. However, due to their inherent toxicity, there is paucity of studies on the sulfur-based drugs, which limits their use in antimalarial treatment (Nzila, 2006). Another evaluation of antimalarial screening of quinazolinones was carried out by Patel et al.,
(2017) both computationally as well as in vitro and its findings revealed their DHFR inhibitory potency. The main contribution of this study stems from identifying five out of nineteen potent antimalarial molecules (Patel et al., 2017).

Other enzymes in folate pathways were defined in an earlier work by Lee et al. (2001), which described the gene that encodes GTP cyclohydrolase I ( $g$ th-ch), catalyzing the conversion of GTP to dihydroneopterin via triphosphate. Polymerase chain reactions and DNA sequencing were performed to isolate the gtp-ch gene of $P$. falciparum. The gene was identified by using six primers and direct sequencing of this fragment discovered an open reading frame that are comparable with the predicted protein sequence and those of known gtp-ch molecules. This gene is attractive for novel antimalarial therapeutic target because it is expressed in blood-stage parasites and $g$ tp-ch provides the rate-limiting steps in folate pathway, as shown in another microorganism (Lee et al., 2001). Years later, Kümpornsin et al. (2014) studied the enzymatic activity and genetic 
complementation for $P$. falciparum GTP cyclohydrolase I (PfGCH1). Its findings indicated that this could be a new approach to antimalarial drug development, since the assay of this enzyme showed an inhibitory effect by 8-oxo-GTP, a known GTP analogue inhibitor (Kümpornsin et al., 2014).

\subsection{Enzymes involved in glycotic pathway}

Finding the alternative molecular targets for antimalarial drug design, specifically on the energy-generating pathway of carbohydrate metabolism is deemed essential in most drug design studies. Glycolysis, the metabolic pathway for carbohydrate metabolism, is an ancient, conserved metabolic energy-producing machinery that converts glucose to pyruvate and lactate under aerobic and anaerobic conditions, respectively. The enzymes in this pathway are crucial for parasite survival and growth. It is wellestablished that $P$. falciparum solely depends on glycolysis for energy generation and meets its energy needs by anaerobic metabolism of glucose to lactate (Sabbatani, Fiorino, \& Manfredi, 2010). Glycolysis occurs in two distinct phases-the preparatory and the payoff phase. The preparatory phase is the glucose activation phase, where phosphorylation of glucose and its conversion to glyceraldehyde-3-phosphate takes place, while the payoff phase is the extraction stage, during which conversion of glyceraldehyde3-phosphate to pyruvate, as well as the coupled formation of ATP, occurs (Giri, 2016). Ten enzymes are involved in glycolysis, namely hexokinase, phosphohexose isomerase, phosphofructokinase-1, aldolase, triosephosphate isomerase, glyceraldehyde 3-phosphate dehydrogenase, phosphoglycerate kinase, phosphoglycerate mutase, enolase, and pyruvate kinase. During anaerobic condition, an additional enzyme-lactate dehydrogenase-is required. Genome sequence analysis by Gardner et al. (2002) has provided a comprehensive understanding of the metabolic potential of $P$. falciparum.

Glycolysis is the key metabolic pathway for ATP production in malaria parasite and is pivotal for its survival during the Plasmodium intraerythrocytic cycle. The glycolysis rate in $P$. falciparum-infected erythrocytes is 20-100 times higher than in uninfected erythrocytes, which renders them valuable indicators of current infections (Iqbal et al., 2004; Singh \& Daneshvar, 2013). In a much earlier study, Roth Jr. et al. (1988) demonstrated that nearly all glycolytic enzymes were upregulated in $P$. falciparum-infected red blood cells (RBC), which was proportional to the parasitemia level. More recently, Kantele \& Jokiranta (2011) revealed that hexokinase, aldolase, enolase, pyruvate kinase, and adenosine deaminase were the most markedly upregulated enzymes. The functions of each enzyme in the glycolytic pathway of malaria parasites have been reviewed extensively by Alam et al. (2014). The authors also investigated the functions of $P$. falciparum glycolytic enzymes as a part of their review. They noted its exceptional structural differences and functional features, suggesting that these could be exploited as therapeutic targets.

Research on Plasmodium lactate dehydrogenase has revealed that $p \mathrm{LDH}$ could be a diagnostic biomarker, as well as antimalarial inhibitory target (Jain et al., 2014; van Niekerk et al., 2016). Manerba et al. (2012) conducted their study aiming to verify galloflavin (CAS 568-80-9) as a novel inhibitor of lactate dehydrogenase. The authors reported that, in cultured tumor cells, galloflavin blocked the aerobic glycolysis at micromolar concentrations, but did not affect the cell respiration or induced cell death by triggering apoptosis. Additionally, 50 commercially-available compounds that have been selected through molecular docking approach were tested by Penna-Coutinho et al. (2011) against $P$. falciparum lactate dehydrogenase (Pf-LDH) and three compounds (itraconazole, atorvastatin and posaconazole) have been identified with the closest binding energy values to NADH. These were subsequently proven active in immunoenzymatic assays. The study findings further demonstrated that molecular docking research can be a reliable approach for discovering new antimalarial drugs (PennaCoutinho et al., 2011). Following an earlier study on azole-based compound, which is also an inhibitor of Pf-LDH, Cameron et al. (2004) suggested that these compounds have limited chances for additional derivatization due to the close contacts made within the active site of the enzyme. As the authors also noted that they appeared to have limited cellular uptake in the current form, they called for further development 
of extended azole-like compounds, which may result a beneficial route for the improvement of novel antimalarials (Cameron et al., 2004).

Other enzymes in the glycolytic pathway of Plasmodium were also widely studied, the glyceraldehyde-3-phosphate dehydrogenase (GAPDH) in particular. GAPDH is a important glycolytic enzyme that catalyzes the oxidation of glyceraldehyde-3-phosphate (G3P) to 1,3biphosphoglycerate (1,3-BPG), coupled to the reduction of nicotinamide adenine dinucleotide (NAD+) to NADH (Bruno et al., 2016). Recent investigations have revealed that this enzyme is promising as a new malaria diagnostic biomarker because native PfGAPDH protein levels were 4 6 times higher than the current target PfLDH (Krause et al., 2017). However, GAPDH has also been explored as potential antimalarial drug target. Compounds based on the 3-Br-isoxazoline scaffold completely inhibit GAPDH from $P$. falciparum by selectively alkylating all four catalytic cysteines of the tetramer, but only inhibit $25 \%$ of human orthologue (hGAPDH) (Bruno et al., 2016).

Hexokinase has also been the subject of extensive research, as it is the first enzyme in the glycolytic pathway. An inhibition study on hexokinase of Trypanosoma cruri, another species of blood protozoa, by bisphosphonates, showed that these non-hydrolyzable analogues of inorganic diphosphate are potent inhibitors of $T$. cruqi hexokinase (Hudock et al., 2005). More recently, Davis et al. (2016) attempted to identify the inhibitor for $P$. falciparum hexokinase, where 57,654 molecules were screened from multiple small-molecule collections. Their findings revealed that the most potent inhibitors (GSK650394 ) have $50 \%$ inhibitory concentrations as low as $\sim 1 \mu \mathrm{M}$, and some were found to have lowmicromolar concentrations (NCGC 00099116 and NCGC00099209) that were 50\% effective against asexual blood stage of $P$. falciparum parasites.

\section{Approaches employed in the discovery of new antimalarial drugs \\ 3.1 Computational approach}

Drug design and discovery pipeline comprises all the drug development stages, from identifying a target to clinical trials for testing the drug on human subjects. Hence, drug discovery is typically considered a time-consuming and costly process. However, computer aided drug design (CADD), a computational technology aimed at assisting the antimalarial drug discovery process, has become indispensable in recent years. It makes use of the structural knowledge of either the target (structure-based) or known ligands with bioactivity (ligand-based) to facilitate the identification of likely candidate drugs (Macalino et al., 2015).

A study benefiting from this approach was performed by Granchi et al. (2015) with the aim of finding new human lactate dehydrogenase 5 (LDH5) inhibitors. As a part of this investigation, an automated docking-based virtual screening platform was developed by considering different protein conformations and the consensus docking strategy. The authors discovered that two of the ten of the selected compounds efficiently inhibit the enzyme activity via enzymatic assays (Granchi et al., 2015). Given that it avoids carrying out enzymatic assays of thousands of compounds, CADD is highly cost- and time-efficient, as it helps optimizing the work in the laboratory. Several studies have been performed using both structure-based drug design (SBDD) and ligandbased drug design (LBDD) approaches in finding new inhibitors for the enzymes in Plasmodium spp. as the target, as summarized in Table 3.

Huthmacher et al. (2010) conducted their study with the goal of elucidating the capability of computational methods to foresee the metabolic activities during different stages of $P$. falciparum life cycle, which later led to the identification of new drug targets. Their findings suggested that the set of significant enzymes projected by flux balance approach signifies a reliable beginning for further drug development (Huthmacher et al., 2010).

\subsection{Natural products}

It well-elucidated that countless compounds for drug discovery can be found in natural products. In the past two decades, their use has declined due to the technical difficulties associated with screening natural products in high-throughput assays compared to molecular targets (Harvey et al., 2015). Azas et al., (2002) evaluated potent in vitro synergistic antimalarial interactions between the extracts of Mitragyna enermis (Willd) O. Kuntze, Rubiaceae, Nauclea latifolia (Sm.) Guera senegalensis (GMel), Combretaceae and Feretia apodhantera 
(Del) by conducting isobologram analysis. The findings yielded revealed that tetrahydroharman isolated from $G$. senegalensis exhibits antimalarial activity with neither cytotoxicity nor genotoxicity found in Salmonella Ames test, with and without metabolic activation (Azas et al., 2002).

Table 3. Implementation of SBDD and LBDD approaches to find new inhibitors in malaria drug discovery

\begin{tabular}{|c|c|c|c|c|}
\hline Methods & Species & Enzyme target & Inhibitor & References \\
\hline $\begin{array}{l}\text { Molecular } \\
\text { modeling }\end{array}$ & $\begin{array}{l}\text { Plasmodium } \\
\text { falciparum }\end{array}$ & Enoyl reductase & $\begin{array}{l}\text { VRC-007 and VRC-009 } \\
\text { (analogues of N- } \\
\text { benzylidene-4-phenyl-1,3- } \\
\text { thiazol2-amine) }\end{array}$ & $\begin{array}{l}\text { (Morde } e t \text { al., } \\
\text { 2009) }\end{array}$ \\
\hline $\begin{array}{l}\text { Molecular } \\
\text { modeling }\end{array}$ & $\begin{array}{l}\text { Plasmodium } \\
\text { falciparum }\end{array}$ & $\begin{array}{l}\text { Dihydroorotate } \\
\text { dehydrogenase }\end{array}$ & $\begin{array}{c}\text { KMC-3 and KMC-15 } \\
\text { (derivatives of N- } \\
\text { phenylbenzamide) }\end{array}$ & $\begin{array}{l}\text { (Desai, Shaikh, \& } \\
\text { Coutinho, 2011) }\end{array}$ \\
\hline $\begin{array}{l}\text { Molecular docking } \\
\text { and 3D-QSAR }\end{array}$ & $\begin{array}{l}\text { Plasmodium } \\
\text { falciparum }\end{array}$ & $\begin{array}{l}\text { Cysteine } \\
\text { proteases }\end{array}$ & $\begin{array}{l}\text { Derivatives of peptidyl vinyl } \\
\text { sulfone }\end{array}$ & $\begin{array}{c}\text { (Teixeira et al., } \\
\text { 2011) }\end{array}$ \\
\hline $\begin{array}{c}\text { 3D-QSAR, } \\
\text { molecular } \\
\text { dynamics, } \\
\text { docking, and } \\
\text { genetic algorithm- } \\
\text { based methods }\end{array}$ & $\begin{array}{l}\text { Plasmodium } \\
\text { falciparum }\end{array}$ & $\begin{array}{l}\text { Dihydroorotate } \\
\text { dehydrogenase }\end{array}$ & $\begin{array}{l}\text { Derivatives of } \\
\text { triazolopyrimidine }\end{array}$ & (Shah et al., 2012) \\
\hline $\begin{array}{l}\text { Modelling the } \\
\text { evolution of drug } \\
\text { resistance in } \\
\text { malaria. }\end{array}$ & Plasmodium & $\begin{array}{l}\text { Dihydrofolate } \\
\text { reductase }\end{array}$ & - & $\begin{array}{l}\text { (Hecht \& Fogel, } \\
\text { 2012) }\end{array}$ \\
\hline $\begin{array}{l}\text { Docking and in } \\
\text { silico ADMET }\end{array}$ & $\begin{array}{l}\text { Plasmodium } \\
\text { falciparum }\end{array}$ & $\begin{array}{l}\text { S-adenosyl-L- } \\
\text { homocysteine } \\
\text { hydrolase }\end{array}$ & $\begin{array}{l}\text { Noraristeromycin, curcumin } \\
\text { and its derivatives }\end{array}$ & (Singh et al., 2013) \\
\hline $\begin{array}{l}\text { Ligand-based 3D- } \\
\text { QSAR analysis } \\
\text { and virtual } \\
\text { screening }\end{array}$ & $\begin{array}{l}\text { Plasmodium } \\
\text { falciparum }\end{array}$ & $\begin{array}{l}\text { Glutathione } \\
\text { reductase }\end{array}$ & $\begin{array}{c}\mathrm{N} \text {-(2,3-dihydrobenzo[b] } \\
\text { [1,4]dioxin-6-yl)-2-(5- } \\
\text { isopropyl4-(2- } \\
\text { methoxyethyl)-4H-1,2,4- } \\
\text { triazol-3-ylthio)acetamide }\end{array}$ & $\begin{array}{l}\text { (Kamaria \& } \\
\text { Kawathekar, } \\
\text { 2014) }\end{array}$ \\
\hline Molecular docking & $\begin{array}{l}\text { Plasmodium } \\
\text { falciparum }\end{array}$ & $\begin{array}{l}\text { Spermidine } \\
\text { synthase }\end{array}$ & $\begin{array}{l}\text { (1R,4R)-(N1-(3- } \\
\text { aminopropyl)-trans- } \\
\text { cyclohexane-1,4-diamine } \\
\text { and analogue N-(3- } \\
\text { aminopropyl)- } \\
\text { cyclohexylamine }\end{array}$ & $\begin{array}{l}\text { (Burger et al., } \\
\text { 2015) }\end{array}$ \\
\hline Molecular docking & $\begin{array}{l}\text { Plasmodium } \\
\text { falciparum }\end{array}$ & Transketolase & $\begin{array}{c}\text { 6'-Methyl-Thiamin } \\
\text { Diphosphate }\end{array}$ & $\begin{array}{l}\text { (Hasan } \text { et al., } \\
\text { 2015) }\end{array}$ \\
\hline In silico screening & $\begin{array}{l}\text { Plasmodium } \\
\text { falciparum }\end{array}$ & $\begin{array}{l}\text { Enoyl-ACP } \\
\text { reductase }\end{array}$ & Pyrimidine diones & $\begin{array}{l}\text { (Lindert et al., } \\
\text { 2015) }\end{array}$ \\
\hline $\begin{array}{c}\text { 3D QSAR, } \\
\text { pharmacophore } \\
\text { and molecular } \\
\text { docking }\end{array}$ & $\begin{array}{l}\text { Plasmodium } \\
\text { falciparum }\end{array}$ & $\begin{array}{l}\text { M18 aspartyl } \\
\text { aminopeptidase }\end{array}$ & $\begin{array}{c}\text { Derivative of quinine, } \\
\text { chloroquine, } 8- \\
\text { aminoquinoline and known } \\
\text { antimalarial M18AAP } \\
\text { inhibitors (AID743024) }\end{array}$ & $\begin{array}{l}\text { (Kumari et al., } \\
\text { 2016) }\end{array}$ \\
\hline
\end{tabular}


More recently, Upadhyay et al. (2014) reported antimalarial potential of extracts and compounds from the chloroform and n-butanol fractions of Ammannia baccifera roots and methanol extract of Ammannia coccinea (AC). These extracts are commonly used in Chinese and Indian medicine as a therapy for diseases. The compounds were isolated from the extracted and fractionated dried and powdered samples, followed by repeated chromatographic separations of the fractions. The compounds effectiveness was demonstrated in vitro through antiplasmodial activity against $P$. falciparum NF-5. Extracts from AC showed potency in antiplasmodial activity and nontoxic to Vero cells. The authors thus concluded that the selective antiplasmodial activity from these plants will be advantageous in antimalarial drug development and discovery of safer therapeutics (Upadhyay et al., 2014).

Thiengsusuk \& Chaijaroenkul (2013) performed an evaluation of antimalarial activities of Thai traditional medicine which consist of 27 medicinal plants and 5 herbal formulations used against chloroquine-resistant (K1) and chloroquine-sensitive (3D7) P. falciparum clones. Their results indicate that that ethanolic extracts from 19 investigated plants/herbal formulations exhibited promising activity against both $\mathrm{K} 1$ and 3D7 clones of $P$. falciparum, with $<50 \%$ survival at the concentration of $50 \mu \mathrm{g} / \mathrm{ml}$. In addition, eight medicinal plants and two herbal formulations that were included in this investigation showed potent antimalarial activity with median range IC50 values $<10 \mu \mathrm{g} / \mathrm{ml}$ against K1 or 3D7 P. falciparum clone or both (Thiengsusuk \& Chaijaroenkul 2013).

Sethiya et al. (2014) screened methanol extract of Evolvulus alsinoides for $P$. falciparum lactate dehydrogenase enzyme inhibitory activity, reporting that E. alsinoides possesses a compound known as scopoletin that potentially inhibits the PfLDH. E. alsinoides is generally recognized as Shankhpushpi and is used in traditional remedy for malarial treatment by some ethnic populations of India (Sethiya et al., 2014).

\subsection{High throughput screening}

High Throughput Screening (HTS) is a drugdiscovery method that is widely used in the pharmaceutical industry. It is an automated process that rapidly assays the biological or biochemical activity of many drug-like compounds. During a typical HTS assay, a collection of chemical composites is carefully chosen and tested against a biological target to evaluate the strength of the related inhibition or activation signal (Malo et al., 2006). In order to successfully identify LDH inhibitors from library of a small molecule compound, two label-free high-throughput assays were planned using a kinetic high-throughput screen (VanderPorten et al., 2013). In addition, examination on antimalarial elements from Berberis thunbergii and Eugenia rigida by automated HTS, using UPLC-MS-ELSD-PDA yielded two triterpenoids, namely $\alpha$-betulinic acid and $\beta$-betulinic acid, that were acknowledged as antimalarial active elements from HTS hits of $E$. rigida (Zhang et al., 2014)

High throughput screening is not only beneficial in the search for antimalarial drugs but is also indispensable in the discovery of small molecules that can interfere malaria transmission. Plouffe et al. (2016) developed a serum-free onestep assay for malaria transmission-blocking activity, which allowed them to analyze 13,983 known and new compounds. The authors noted that more than $90 \%$ recognized antimalarial drugs do not show activity to the late-stage gametocytes. Another high-throughput matrix screening approach was tested by Mott et al. (2015) on 13,910 approved and investigational drugs, allowing the researchers to identify several synergistic and antagonistic antimalarial drug combinations.

\section{CONCLUSION}

Malaria is a global issue, with the ongoing malaria transmission, there is a possibility for drug resistance to occur through increasing introduction of parasites to suboptimal drug levels. The growing resistance of P. falciparum to the established antimalarial drugs highlights the need for developing alternative drug regimens. Thus, identifying compounds that may disrupt the enzymes activities that have high control over the pathway's flux may lead to the discovery of novel and effective antimalarial drugs. 


\section{ACKNOWLEDGEMENTS}

This work was supported by the International Islamic University Malaysia Research Initiative Grant Scheme (RIGS15-141-0141).

\section{REFERENCES}

Alam, A., Neyaz, M. K., \& Ikramul Hasan, S. 2014. Exploiting unique structural and functional properties of malarial glycolytic enzymes for antimalarial drug development. Malaria Research and Treatment 2014: 451065.

Alemu, A., Fuehrer, H.-P., Getnet, G., Tessema, B., \& Noedl, H. 2013. Plasmodium ovale curtisi and Plasmodium ovale wallikeri in North-West Ethiopia. Malaria Journal 12(1): 346.

Ariey, F., Witkowski, B., Amaratunga, C., Beghain, J., Langlois, A.C., Khim, N., Kim, S., Duru, V., Bouchier, C., Ma, L., Lim, P., Leang, R., Duong, S., Sreng, S., Suon, S., Chuor, C. M., Bout, D. M., Ménard, S., Rogers, W. O., Genton, B., Fandeur, T., Miotto, O., Ringwald, P., Le Bras, J., Berry, A., Barale, J. C., Fairhurst, R. M., Benoit-Vical, F., MercereauPuijalon, O. \& Ménard, D. 2014. A molecular marker of artemisinin-resistant Plasmodium falciparum malaria. Nature 505(7481): 50-55.

Autino, B., Noris, A., Russo, R., \& Castelli, F. 2012. Epidemiology of malaria in endemic areas. Mediterranean Journal of Hematology and Infectious Diseases 4(1): e2012060.

Azas, N., Laurencin, N., Delmas, F., Di, G. C., Gasquet, M., Laget, M. \& Timon-David, P. 2002. Synergistic in vitro antimalarial activity of plant extracts used as traditional herbal remedies in Mali. Parasitology Research 88(2): 165-171.

Blount, R. E. 1967. Management of chloroquine resistant falciparum malaria. Transactions of the American Clinical and Climatological Association 78: 196-204.

Botté, C. Y., Dubar, F., McFadden, G. I., Maréchal, E., \& Biot, C. 2012. Plasmodium falciparum Apicoplast Drugs: Targets or Off-Targets? Chemical Reviews 112(3): 1269-1283.

Bruno, S., Margiotta, M., Pinto, A., Cullia, G., Conti, P., De Micheli, C., \& Mozzarelli, A. 2016. Selectivity of 3-bromoisoxazoline inhibitors between human and Plasmodium falciparum glyceraldehyde-3-phosphate dehydrogenases. Bioorganic and Medicinal Chemistry 24(12): 2654-2659.

Bueno, J. M., Herreros, E., Angulo-Barturen, I., Ferrer, S., Fiandor, J. M., Gamo, F. J., Gargallo-Viola, D. \& Derimanov, G. 2012. Exploration of 4(1H)-pyridones as a novel family of potent antimalarial inhibitors of the plasmodial cytochrome bc1. Future Medicinal Chemistry 4(18): 2311-2323.

Burger, P. B., Williams, M., Sprenger, J., Reeksting, S. B., Botha, M., Müller, I. B., Joubert, F., Birkholtz, L. M. \& Louw, A. I. 2015. A novel inhibitor of Plasmodium falciparum spermidine synthase: a twist in the tail. Malaria Journal 14(1): 54.

Burrows, J. N., Duparc, S., Gutteridge, W. E., Huijsduijnen, R. H. Van, Kaszubska, W., Macintyre, F., Mazzuri, S., Möhrle, J. J. \& Wells, T. N. C. 2017. New developments in anti malarial target candidate and product profiles. Malaria Journal 16: 26 .

Cameron, A., Read, J., Tranter, R., Winter, V. J., Sessions, R. B., Brady, R. L., Vivas, L., Easton, A., Kendrick, H., Croft, S. L., Barros, D., Lavandera, J. L., Martin, J. J., Risco, F., García-Ochoa, S., Gamo, F.J., Sanz, L., Leon, L., Ruiz, J. R., Gabarró, R., Mallo, A. \& de las Heras, F. G. 2004. Identification and activity of a series of azole-based compounds with lactate dehydrogenase-directed antimalarial activity. Journal of Biological Chemistry 279(30): 31429-31439.

CDC. 2015. Malaria Diagnosis \& Treatment in the United States. Retrieved December 2017, from Centre for Disease Control.

Cheemadan, S., Ramadoss, R., \& Bozdech, Z. 2014. Role of calcium signaling in the transcriptional regulation of the apicoplast genome of Plasmodium falciparum. BioMed Research International 2014: 869401.

da Silva, A. F. C., \& Benchimol, J. L. 2014. Malaria and quinine resistance: a medical and scientific issue between Brazil and Germany (1907-19). Medical History 58(01): 1-26.

Das, A., Syin, C., Fujioka, H., Zheng, H., Goldman, N., Aikawa, M., \& Kumar, N. 1997. Molecular characterization and ultrastructural localization of Plasmodium falciparum Hsp 60. Molecular and Biochemical Parasitology 88(1-2): 95-104.

Davies, M., Heikkilä, T., McConkey, G. A., Fishwick, C. W. G., Parsons, M. R., \& Johnson, A. P. 2009. Structure-Based design, synthesis, and characterization of inhibitors of human and Plasmodium falciparum dihydroorotate dehydrogenases. Journal of Medicinal Chemistry 52(9): 2683 2693.

Davis, M. I., Patrick, S. L., Blanding, W. M., Dwivedi, V., Suryadi, J., Golden, J. E., Coussens, N. P., Lee, O. W., Shen, M., Boxer, M. B., Hall, M. D., Sharlow, E. R., Drew, M. E. \& Morris, J. C. 2016. Identification of novel Plasmodium falciparum hexokinase inhibitors with antiparasitic activity. Antimicrobial Agents and Chemotherapy 60(10): 6023-6033.

Desai, K. R., Shaikh, M. S., \& Coutinho, E. C. 2011. Molecular modeling studies, synthesis and biological evaluation of derivatives of $\mathrm{N}$-phenylbenzamide as Plasmodium falciparum dihydroorotate dehydrogenase (PfDHODH) inhibitors. Medicinal Chemistry Research 20(3): 321-332.

Dong, C. K., Argaonkar, S., Cortese, J. F., Gamo, F.-J., GarciaBustos, J. F., Lafuente, M. J., Patel, V., Ross, L., Coleman, B. I., Derbyshire, E. R., Clish, C. B., Serrano, A. E., Cromwell, M., Barker, R. H. Jr., Dvorin, J. D., Duraisingh, M. T., Wirth, D. F., Clardy, J. \& Mazitschek, R. 2011. Identification and validation of tetracyclic benzothiazepines as Plasmodium falciparum cytochrome $b c_{1}$ inhibitors. Chemistry \& Biology 18(12): 1602-1610.

Fornace, K. M., Abidin, T. R., Alexander, N., Brock, P., Grigg, M. J., Murphy, A., William, T., Menon, J., Drakeley, C. J. \& Cox, J. 2016. Association between landscape factors and spatial patterns of Plasmodium knowlesi infections in Sabah, Malaysia. Emerging Infectious Diseases 22(2): 201-208.

Gardner, M. J., Hall, N., Fung, E., White, O., Berriman, M., Hyman, R. W., Carlton, J. M., Pain, A., Nelson, K. E., Bowman. S., Paulsen, I. T., James, K., ,Eisen, J. A., Rutherford, K., Salzberg, S. L., Craig, A., Kyes, S., Chan, M. S., Nene, V., Shallom, S. J., Suh, B., Peterson, J., Angiuoli, S., Pertea, M., Allen, J., Selengut, J., Haft, D., Mather, M. W., Vaidya, A. B., Martin, D. M., Fairlamb, A. H., Fraunholz, M. J., Roos, D. S., Ralph, S. A., McFadden, G. I., Cummings, L. M., Subramanian, G. M., Mungall, C., Venter, J. C., Carucci, D. J., Hoffman, S. L., Newbold, C., Davis, R. W., Fraser, C. M. \& Barrell, B. 2002. Genome sequence of the human malaria parasite Plasmodium falciparum. Nature 419(6906): 498-511.

Giri, D. 2016. Glycolysis: All steps with diagram, enzymes, products, energy yield and significance. Retrieved October 2017, from LaboratoryInfo.com Website: http://laboratoryinfo.com/glycolysis-steps-diagramenergy-yield-and-significance/

Granchi, C., Capecchi, A., Del Frate, G., Martinelli, A., Macchia, M., Minutolo, F., \& Tuccinardi, T. 2015. Development and validation of a docking-based virtual screening platform for 
the identification of new lactate dehydrogenase inhibitors. Molecules 20(5): 8772-8790.

Gujjar, R., El Mazouni, F., White, K. L., White, J., Creason, S., Shackleford, D. M., Deng, X., Charman, W. N., Bathurst, I., Burrows, J., Floyd, D. M., Matthews, D., Buckner, F. S., Charman, S. A., Phillips, M. A. \& Rathod, P. K. 2011. Lead optimization of aryl and aralkyl amine-based triazolopyrimidine inhibitors of Plasmodium falciparum dihydroorotate dehydrogenase with antimalarial activity in mice. Journal of Medicinal Chemistry 54(11): 3935-3949.

Gujjar, R., Marwaha, A., El Mazouni, F., White, J., White, K. L., Creason, S., Shackleford, D. M., Baldwin, J., Charman, W. N., Buckner, F. S., Charman, S., Rathod, P. K. \& Phillips, M. A. 2009. Identification of a metabolically stable triazolopyrimidine-based dihydroorotate dehydrogenase inhibitor with antimalarial activity in mice. Journal of Medicinal Chemistry 52(7): 1864-1872.

Harvey, A. L., Edrada-Ebel, R., \& Quinn, R. J. 2015. The reemergence of natural products for drug discovery in the genomics era. Nature Reviews Drug Discovery 14(2): 111-129.

Hasan, M. A., Mazumder, M. H. H., Chowdhury, A. S., Datta, A., \& Khan, M. A. 2015. Molecular-docking study of malaria drug target enzyme transketolase in Plasmodium falciparum 3D7 portends the novel approach to its treatment. Source Code for Biology and Medicine 10(1): 7.

Hecht, D. \& Fogel, G. B. 2012. Modeling the evolution of drug resistance in malaria. Journal of Computer-Aided Molecular Design 26(12): 1343-1353.

Hikosaka, K., Watanabe, Y., Kobayashi, F., Waki, S., Kita, K., \& Tanabe, K. 2011. Highly conserved gene arrangement of the mitochondrial genomes of 23 Plasmodium species. Parasitology International 60(2): 175-180.

Hikosaka, K., Komatsuya, K., Suzuki, S., \& Kita, K. 2015. Mitochondria of malaria parasites as a drug target. An Overview of Tropical Diseases.

Hudock, M. P., C. E. Sanz-Rodríguez, Yongcheng Song, Chan, J. M. W., Zhang, Y., Odeh, S., Kosztowski, T., Leon-Rossell, A., Concepción, J.L., Yardley, V., Croft, S.L., Urbina, J.A. \& Oldfield, E. 2006. Inhibition of Trypanosoma cruri Hexokinase by Bisphosphonates. Journal of Medical Chemistry 12(29): 215-223.

Huthmacher, C., Hoppe, A., Bulik, S., \& Holzhütter, H. G. 2010. Antimalarial drug targets in Plasmodium falciparum predicted by stage-specific metabolic network analysis. BMC Systems Biology 4(1): 120.

Hyde, J. E. 2005. Exploring the folate pathway in Plasmodium falciparum. Acta Tropica, 94(3): 191-206.

Iqbal, J., Siddique, A., Jameel, M., \& Hira, P. R. 2004. Persistent histidine-rich protein 2 , parasite lactate dehydrogenase, and panmalarial antigen reactivity after clearance of Plasmodium falciparum monoinfection. Journal of Clinical Microbiology 42(9): 4237-424.

Jagoe, G. 2018. Malaria progress has levelled but new drugs are due.

Jain, P., Chakma, B., Patra, S., \& Goswami, P. 2014. Potential biomarkers and their applications for rapid and reliable detection of malaria. BioMed Research International 2014: 852645.

Kabanywanyi, A. M., Mwita, A., Sumari, D., Mandike, R., Mugittu, K., \& Abdulla, S. 2007. Efficacy and safety of artemisininbased antimalarial in the treatment of uncomplicated malaria in children in southern Tanzania. Malaria Journal 6(1): 146.

Kamaria, P., \& Kawathekar, N. 2014. Ligand-based 3D-QSAR analysis and virtual screening in exploration of new scaffolds as Plasmodium falciparum glutathione reductase inhibitors. Medicinal Chemistry Research 23(1): 25-33.
Ke, H., Lewis, I. A., Morrisey, J. M., McLean, K. J., Ganesan, S. M., Painter, H. J., Mather, M. W., Jacobs-Lorena, M., Llinás, M. \& Vaidya, A. B. 2015. Genetic investigation of tricarboxylic acid metabolism during the Plasmodium falciparum life cycle. Cell Reports 11(1): 164-174.

Klonis, N., Creek, D. J., \& Tilley, L. 2013. Iron and heme metabolism in Plasmodium falciparum and the mechanism of action of artemisinins. Current Opinion in Microbiology 16(6): 722-727.

Köhler, S., Delwiche, C. F., Denny, P. W., Tilney, L. G., Webster, P., Wilson, R. J., Palmer, J. D. \& Roos, D. S. 1997. A plastid of probable green algal origin in Apicomplexan parasites. Science 275(5305): 1485-1489.

Krause, R. G. E., Hurdayal, R., Choveaux, D., Przyborski, J. M., Coetzer, T. H. T., \& Goldring, J. P. D. 2017. Plasmodium glyceraldehyde-3-phosphate dehydrogenase: A potential malaria diagnostic target. Experimental Parasitology 179: 7-19.

Kumari, M., Chandra, S., Tiwari, N., \& Subbarao, N. 2016. 3D QSAR, pharmacophore and molecular docking studies of known inhibitors and designing of novel inhibitors for M18 aspartyl aminopeptidase of Plasmodium falciparum. BMC Structural Biology 16(1): 12.

Kümpornsin, K., Kotanan, N., Chobson, P., Kochakarn, T., Jirawatcharadech, P., Jaru-ampornpan, P., Yuthavong, Y. \& Chookajorn, T. 2014. Biochemical and functional characterization of Plasmodium falciparum GTP cyclohydrolase I. Malaria Journal 13(1): 150.

Lacerda, M. V. G., Llanos-Cuentas, A., Krudsood, S., Lon, C., Saunders, D. L., Mohammed, R., Yilma, D., Pereira, D., E J Espino, F., Z Mia, R., Chuquiyauri, R., Val, F., Casapía, M., Monteiro, W., Brito, A. M. M., Costa, R. F. M., Buathong, N., Noedl, H., Diro, E. \& Koh, G. 2019. SingleDose Tafenoquine to Prevent Relapse of Plasmodium vivax Malaria. New England Journal of Medicine 380(3): 215-228.

Leung, S. C., Gibbons, P., Amewu, R., Nixon, G. L., Pidathala, C., Hong, W. D., Pacorel, B., Berry, N.G., Sharma, R., Stocks, P.A., Srivastava, A., Shone, A.E., Charoensutthivarakul, S., Taylor, L., Berger, O., Mbekeani, A., Hill, A., Fisher, N.E., Warman, A.J., Biagini, G.A., Ward, S.A. \& O'Neill, P. M. 2012. Identification, design and biological evaluation of heterocyclic quinolones targeting Plasmodium falciparum Type II NADH: quinone oxidoreductase (PfNDH2). Journal of Medicinal Chemistry 55(5): 1844-1857.

Lindert, S., Tallorin, L., Nguyen, Q. G., Burkart, M. D., \& McCammon, J. A. 2015. In silico screening for Plasmodium falciparum enoyl-ACP reductase inhibitors. Journal of Computer-Aided Molecular Design 29(1): 79-87.

Lunev, S., Batista, F. A., Bosch, S. S., Wrenger, C., \& Groves, M. R. 2016. Identification and validation of novel drug targets for the treatment of Plasmodium falciparum Malaria: new insights.

Macalino, S. J. Y., Gosu, V., Hong, S., \& Choi, S. 2015. Role of computer-aided drug design in modern drug discovery. Archives of Pharmacal Research 38(9): 1686-1701.

Macraild, C. A., Anders, R. F., Foley, M., \& Norton, R. S. 2011. Apical Membrane Antigen 1 as an Anti-Malarial Drug Target. 2039-2047.

Malo, N., Hanley, J. A., Cerquozzi, S., Pelletier, J., \& Nadon, R. 2006. Statistical practice in high-throughput screening data analysis. Nature Biotechnology 24(2): 167-175.

Manerba, M., Vettraino, M., Fiume, L., Stefano, D., Sartini, A., Giacomini, E., Buonfiglio, R., Roberti, M. \& Recanatini, M. 2012. Galloflavin (CAS 568-80-9): A novel inhibitor of lactate dehydrogenase. ChemMedChem 7(2): 311-7311-317.

McFadden, G. I., Reith, M. E., Munholland, J., \& Lang-Unnasch, N. 1996. Plastid in human parasites. Nature 381(6582): 482482. 
Mohapatra, P. K., Sarma, D. K., Prakash, A., Bora, K., Ahmed, M. A., Sarma, B., Goswami, B. K., Bhattacharyya, D.R. \& Mahanta, J. 2014. Molecular Evidence of Increased Resistance to Anti-Folate Drugs in Plasmodium falciparum in North-East India: A Signal for Potential Failure of Artemisinin Plus Sulphadoxine-Pyrimethamine Combination Therapy. PLoS ONE 9(9): e105562.

Morde, V. A., Shaikh, M. S., Pissurlenkar, R. R. S., \& Coutinho, E. C. 2009. Molecular modeling studies, synthesis, and biological evaluation of Plasmodium falciparum enoyl-acyl carrier protein reductase (PfENR) inhibitors. Molecular Diversity 13(4): 501-517.

Mukherjee, A., \& Sadhukhan, G. C. 2016. Anti-malarial Drug Design by Targeting Apicoplasts : New Perspectives. Journal of Pharmacopuncture 19(1): 7-15.

Nzila, A. 2006. The past, present and future of antifolates in the treatment of Plasmodium falciparum infection. Journal of Antimicrobial Chemotherapy 57(6): 1043-1054.

Okombo, J., \& Chibale, K. 2018. Recent updates in the discovery and development of novel antimalarial drug candidates. MedChem Comm 9(3): 437-453.

Olliaro, P. L., \& Mussano, P. 2003. Amodiaquine for treating malaria. Cochrane Database of Systematic Reviews (2): CD000016.

Olszewska, A., \& Szewczyk, A. 2013. Critical Review Mitochondria as a Pharmacological Target: Magnum Overview. IUBMB Life 65(3): 273-281.

Patel, T. S., Vanparia, S. F., Patel, U. H., Dixit, R. B., Chudasama, C. J., Patel, B. D., \& Dixit, B. C. 2017. Novel 2,3disubstituted quinazoline-4 $(3 \mathrm{H})$-one molecules derived from amino acid linked sulphonamide as a potent malarial antifolates for DHFR inhibition. European Journal of Medicinal Chemistry 129: 251-265.

Patel, V., Booker, M., Kramer, M., Ross, L., Celatka, C. A., Kennedy, L. M., Dvorin, J. D., Duraisingh, M. T., Sliz, P., Wirth, D. F. \& Clardy, J. 2008. Identification and characterization of small molecule inhibitors of Plasmodium falciparum dihydroorotate dehydrogenase. Journal of Biological Chemistry 283(50): 35078-35085.

Penna-Coutinho, J., Cortopassi, W. A., Oliveira, A. A., França, T. C. C., \& Krettli, A. U. 2011. Antimalarial activity of potential inhibitors of Plasmodium falciparum lactate dehydrogenase enzyme selected by docking studies. PLoS ONE 6(7): e21237.

Phillips, M. A., Burrows, J. N., Manyando, C., Rob Hooft van Huijsduijnen, R. H., Van Voorhis, W. C. \& Wells, T. N. C. 2017. Malaria. Nature Reviews Disease Primers 3: 17051.

Rai, M., Ingle, A. P., Paralikar, P., Gupta, I., Medici, S., \& Santos, C. A. 2017. Recent advances in use of silver nanoparticles as antimalarial agents. International Journal of Pharmaceutics 526(1-2): 254-270

Rai, P., Sharma, D., Soni, R., Khatoon, N., Sharma, B., \& Bhatt, T. K. 2017. Plasmodium falciparum apicoplast and its transcriptional regulation through calcium signaling. Journal of Microbiology 55(4): 231-236.

Ralph, S. A., D'Ombrain, M. C., \& McFadden, G. I. 2001. The apicoplast as an antimalarial drug target. Drug Resistance Updates 4(3): 145-151.

Ringwald, P., Barrette, A., Rasmussen, C., \& Newman, R. D. 2012. The global challenge of antimalarial drug resistance. Malaria Journal 11(Suppl 1): O37.

Rowe, A. K., Rowe, S. Y., Snow, R. W., Korenromp, E. L., Schellenberg, J. R. A., Stein, C., Nahlen, B.L., Bryce, J., Black, R.E. \& Steketee, R. W. 2006. The burden of malaria mortality among African children in the year 2000. International Journal of Epidemiology 35(3): 691-704.

Sabbatani, S., Fiorino, S., \& Manfredi, R. 2010. The emerging of the fifth malaria parasite (Plasmodium knowlesi). A public health concern? The Brazilian Journal of Infectious Diseases 14(3): 299-309.

Sethiya, N., Keluskar, P., Ingle, S., \& Mishra, S. 2014. Antimalarial activity of Evolvulus alsinoids Linn.-an in vitro Plasmodium falciparum specific lactate dehydrogenase enzyme inhibition assay. Asian Pacific Journal of Tropical Disease 4(6): 489-491.

Shah, P., Kumar, S., Tiwari, S., \& Siddiqi, M. I. 2012. 3D-QSAR studies of triazolopyrimidine derivatives of Plasmodium falciparum dihydroorotate dehydrogenase inhibitors using a combination of molecular dynamics, docking, and genetic algorithm-based methods. Journal of Chemical Biology 5(3): 91 103.

Singh, B. \& Daneshvar, C. 2013. Human infections and detection of Plasmodium knowlesi. Clinical Microbiology Reviews 26(2): 165-184.

Singh, D. B., Gupta, M. K., Singh, D. V., Singh, S. K., \& Misra, K. 2013. Docking and in silico ADMET studies of noraristeromycin, curcumin and its derivatives with Plasmodium falciparum SAH hydrolase: A molecular drug target against malaria. Interdisciplinary Sciences: Computational Life Sciences 5(1): 1-12.

Straimer, J., Gnadig, N. F., Witkowski, B., Amaratunga, C., Duru, V., Ramadani, A. P., Dacheux, M., Khim, N., Zhang, L., Lam, S., Gregory, P. D., Urnov, F. D., Mercereau-Puijalon, O., Benoit-Vical, F., Fairhurst, R. M., Ménard, D. \& Fidock, D. A. 2015. K13-propeller mutations confer artemisinin resistance in Plasmodium falciparum clinical isolates. Science 347(6220): 428-431.

Sutherland, C. J., Tanomsing, N., Nolder, D., Oguike, M., Jennison, C., Pukrittayakamee, S., Dolecek, C., Hien, T. T., do Rosário, V. E., Arez, A. P., Pinto, J., Michon, P., Escalante, A. A., Nosten, F., Burke, M., Lee, R., Blaze, M., Otto, T. D., Barnwell, J. W., Pain, A., Williams, J., White, N. J., Day, N.P., Snounou, G., Lockhart, P. J., Chiodini, P. L., Imwong, M. \& Polley, S. D. 2010. Two nonrecombining sympatric forms of the human malaria parasite Plasmodium ovale occur globally. The Journal of Infectious Diseases 201(10): 1544-1550.

Tan, L. L., Lau, T. Y., Timothy, W., \& Prabakaran, D. 2014. Fulllength sequence analysis of chloroquine resistance transporter gene in Plasmodium falciparum isolates from Sabah, Malaysia. The Scientific World Journal 2014: 935846.

Teixeira, C., Gomes, J. R. B., Couesnon, T., \& Gomes, P. 2011. Molecular docking and 3D-quantitative structure activity relationship analyses of peptidyl vinyl sulfones: Plasmodium falciparum cysteine proteases inhibitors. Journal of ComputerAided Molecular Design 25(8): 763-775.

Tewari, S. G., Prigge, S. T., Reifman, J., \& Wallqvist, A. 2017. Using a genome-scale metabolic network model to elucidate the mechanism of chloroquine action in Plasmodium falciparum. International Journal for Parasitology. Drugs and Drug Resistance 7(2), 138-146.

Thiengsusuk, A., \& Chaijaroenkul, W. 2013. Antimalarial activities of medicinal plants and herbal formulations used in Thai traditional medicine. Parasitology Research. 112(4):1475-81.

Trampuz, A., Jereb, M., Muzlovic, I., \& Prabhu, R. M. 2003. Clinical review: Severe malaria. Critical Care 7(4): 315-323.

Upadhyay, H. C., Sisodia, B. S., Agrawal, J., Pal, A., Darokar, M. P., \& Srivastava, S. K. 2014. Antimalarial potential of extracts and isolated compounds from four species of genus Ammannia. Medicinal Chemistry Research 23(2): 870-876.

Van Dooren, G. G., Stimmler, L. M., \& McFadden, G. I. 2006. Metabolic maps and functions of the Plasmodium mitochondrion. FEMS Microbiology Reviews 30(4): 596-630.

Van Niekerk, D. D., Penkler, G. P., du Toit, F., \& Snoep, J. L. 2016. Targeting glycolysis in the malaria parasite Plasmodium falciparum. FEBS Journal 283(4): 634-646. 
Vander Jagt, D. L., Hunsaker, L. A., Campos, N. M., \& Baack, B. R. 1990. D-lactate production in erythrocytes infected with Plasmodium falciparum. Molecular and Biochemical Parasitology 42(2): 277-284

VanderPorten, E., Frick, L., Turincio, R., Thana, P., LaMarr, W., \& Liu, Y. 2013. Label-free high-throughput assays to screen and characterize novel lactate dehydrogenase inhibitors. Analytical Biochemistry 441(2): 115-122.

White, N. J. 2008. Plasmodium knowlesi: the fifth human malaria parasite. Clinical Infectious Diseases: An Official Publication of the Infectious Diseases Society of America 46(2): 172-173.

WHO. 2015. Guideline for the Treatment of Malaria. Retrieved April 2019, from World Health Organization Website: http://www.who.int.

WHO. 2018. Antimalarial drug resistance in the Greater Mekong Subregion: How concerned should we be? Retrieved August 2018 from World Health Organization Website.

WHO. 2017. World Malaria Report 2016. World Health Organizations.

William, T., Menon, J., Rajahram, G., Chan, L., Ma, G., Donaldson, S., Khoo, S., Frederick, C., Jelip, J., Anstey, N. M. \& Yeo, T. W. 2011. Severe Plasmodium knowlesi malaria in a tertiary care hospital, Sabah, Malaysia. Emerging Infectious Diseases 17(7): 1248-1255.

World Health Organization. 2015. Treatment of Severe Malaria. Guidelines For The Treatment of Malaria 71-88.

Yusof, R., Ahmed, M. A., Jelip, J., Ngian, H. U., Mustakim, S., Hussin, H. M., Fong, M. Y., Mahmud, R., Sitam, F. T., Japning, J. R., Snounou, G., Escalante, A. A., \& Lau, Y. L. 2016. Phylogeographic evidence for 2 genetically distinct zoonotic Plasmodium knowlesi parasites, Malaysia. Emerging Infectious Diseases 22(8): 1371-1380.

Zhang, J., Tu, Y., Smithson, D., Samoylenko, V., Khan, S., Jacob, M., Tekwani, B., Hester, J. P. Zaki, M., Wang, M., Shelat, A., Jeffries, C., Walker, L., Guy, K., \& Muhammad, I. 2014. Antimalarial constituents from a high-throughput UPLCMS-ELSD-PDA generated natural product library. Planta Medica 80(10): PD126. 